\title{
Drivers and Impacts of ICT Adoption on Transport and Logistics Services
}

\author{
Antonio Hidalgo and Vicente López \\ Department of Business Administration, School of Industrial Engineening, \\ Universidad Politécnica de Madrid, José Gutiérrez Abascal, 2, 28006 Madrid, Spain \\ (comesponding author: ahidalgo(a)etsii.upm.es) \\ Department of Business Administration, School of Industrial Engineering, \\ Universidad Politécnica de Madrid, José Gutiérrez Abascal, 2, 28006 Madrid, Spain
}

\section{Summary}

The availability of high-quality transport and logistics services (TLS) is of paramount importance for the growth and competitiveness of an economy. The objective of this paper is to describe how European companies in this industry use information and communication technology (ICT) for conducting business and to assess the impact of this development for firms and the industry as a whole. A comparison with some important Asia Pacific economies is also presented, indicating that some of these countries (Singapore, Hong Kong. Japan. Taiwan. and Korea) boast very good transport infrastructure compared with the most developed European economies.

Using the structure-conduct-performance (SCP) model and the bi-directional relationships of its elements, the paper identifies the links between ICT adoption and market structure, innovation dynamics. and firm performance. A set of recommendations on how to further improve the actual scenario of e-business in the TLS industry is also presented. The model could also be implemented in Asian countries

Keywords: ICT, e-business. transport services. logistics services. innovation

\section{Introduction}

Today, business organizations face a more complex and competitive environment than ever before (Porter \& Stern, 2001). As trade barriers crumble and less-developed countries enter the competitive marketplace, firms now confront a greater number of competitors that are 
capable of introducing new products and services faster and at cheaper costs (Garten, 1998). Furthermore, as consumers have become more discriminating and demanding (Ellinger, Daugherty \& Gustin, 1997), product life cycles have been shortened, forcing firms to contract time to commercialization (Lovelace, Shapiro \& Weingart, 2001) and provide higher levels of customer service and customized products. Consequently, most firms have entered into a highly conpetitive marketplace characterized by an increase in competition, uncertainty, and complexity (Merrifield, 2000).

In this business environment, imnovation of organizational processes is a major business challenge and is critical for firms' success (Veliyath \& Fitzgerald, 2000). If firms focused on reducing costs and improving quality to gain a competitive advantage in the past, companies today must be able to imnovate at the global frontier and create and commercialize a stream of new products and processes that shift the technology frontier (Porter \& Stern, 2001). One area of innovation that has been the focus of significant discussion is ICT adoption, which has the capacity to impact organizational structure, firm strategy, operational procedures, and buyer-supplier relationships (Williams, et al., 1997).

The swift development of ICT, as well as the declining prices for its use, has considerably enhanced its diffusion during the last few years. As a consequence, the impact of ICT on productivity has become a broadly discussed topic in management sciences, and several studies find empirical evidence for the positive productivity effects of ICT at the firm level (Brynjolfsson \& Hitt, 1996; Licht \& Moch, 1999). Nevertheless, ICT adoption may increase organizational flexibility and competitiveness (Patterson, Grimm \& Corsi, 2003).

The TLS industry is recognized as one of the key component of a successful economy, enabling the movement of goods, services, and people as efficiently as possible. These should arrive in time at the right destination, retaining the right quantities and quality while respecting the level of service selected for the process (Bowersox \& Calantone, 1998). ICT systems are critical for managing TLS firms (Lewis \& Talayevsky, 1997) because they need to manage information effectively and integrate several activities, including inbound and outbound transportation, distribution, warehousing, and fleet management, in order to streamline the physical product flows of their customers

ICTs are important since they make available the right information at the right time and place. This popular logistical paradigm, which most often refers to physical goods, is shown to have equal relevance in the management of information (Lee, Padmanabhan \& Whang, 1997; Levary, 2000). Using e-business technologies, TLS companies can improve their efficiency and productivity, create an integrated approach linking transport modes in innovative ways, and thus improve the quality of their services (Patterson, Grimm \& Corsi, 2003). 
The objective of this paper is to describe how companies in the TLS industry use ICT for conducting business and to assess the impact of this development for firms and the industry as a whole. The paper is organized as follows. In Section 2, the conceptual framework for the analysis of drivers and impacts of ICT adoption is discussed. In addition, the main theoretical hypotheses are implemented, focusing on the critical role of ICT for innovation in the TLS industry in three different dimensions: innovation dynamics, market structure, and firm performance. Section 3 provides the methodology and presents the relevant empirical results. Section 4concludes with some comments on the implications of the findings and some recommendations on how to improve the actual scenario of e-business in the TLS industry.

\section{Theoretical Approach and Hypotheses}

Economic literature suggests that the adoption and diffusion of ICTs among firms in the general economy are striking examples of the possible dynamics of technological change and economic development (Carayannis \& Turner, 2006). For example, if we take a look the different stages of development of some Asian economies, as seen in Table 1 (which can be divided into three main groups: developed countries, developing countries, and countries in transition), it is easy to observe a simple correlation between their development stages and the general situation of ICT applications.

Table 1: ICT Applications by Different Asian Economies Related to Their Development Stage

\begin{tabular}{l|l}
\hline \multicolumn{1}{c|}{ Developing countries } & \multicolumn{1}{c}{ ICT applications } \\
\hline $\begin{array}{l}\text { China, Indonesia, Malaysia } \\
\text { The Philippines, Thailand }\end{array}$ & $\begin{array}{l}\text { There are a number of ICT applications in these countries. However, } \\
\text { some of these technologies are in the introduction stage, and their } \\
\text { application is not as comprehensive when compared to that in more } \\
\text { developed countries. }\end{array}$ \\
\hline $\begin{array}{l}\text { Japan, Korea, Singapore } \\
\text { Taiwán, Hong Kong }\end{array}$ & $\begin{array}{l}\text { These countries have formulated and passed their own laws } \\
\text { concerning the promotion of ICT in trade, logistics, and } \\
\text { transportation. }\end{array}$ \\
\hline $\begin{array}{l}\text { Cambodia, Laos, } \\
\text { Myanmar, Vietnam }\end{array}$ & $\begin{array}{l}\text { These countries still do not have any major application of ICT in } \\
\text { transport, let alone in logistics. }\end{array}$ \\
\hline
\end{tabular}




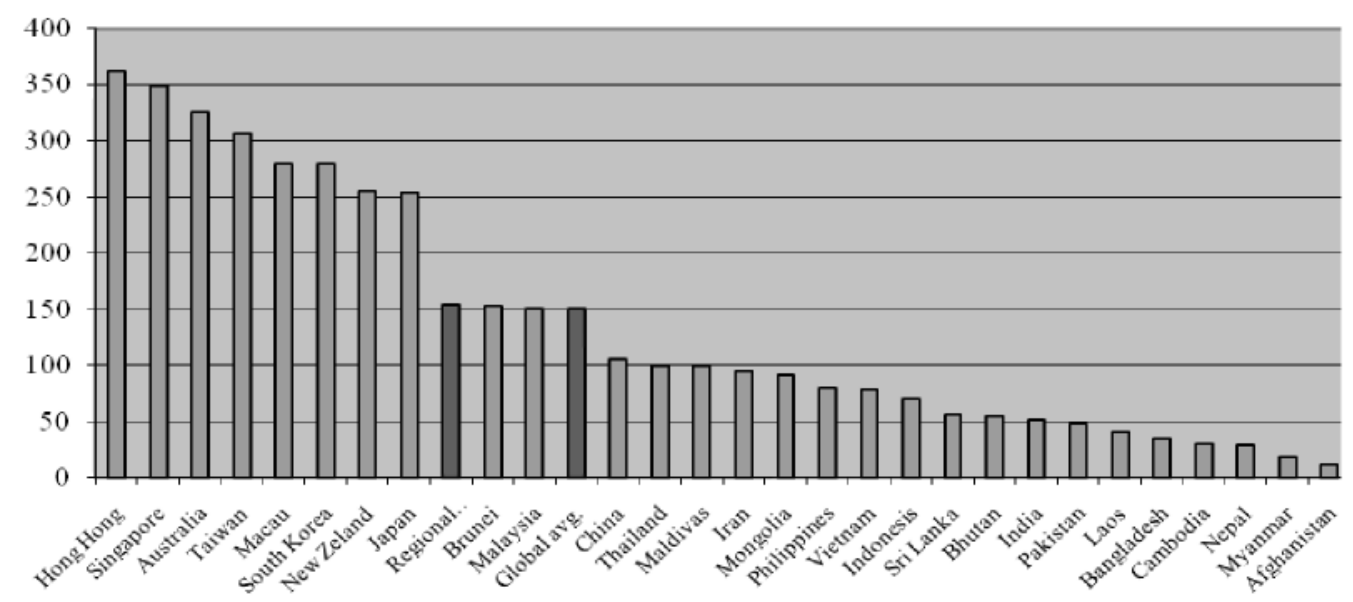

Source: Georges, (2007), State and Evolution of ICTs: A Tale of Two Asias, The International Development Research Centre, Canada.

Figure 1: ICT Opportunities Index in the Asia Pacific 2005

This fact can also be observed in the magnitude of gaps among Asia Pacific economies in the ICT opportunities index shown in Figure 1 (Sciadas, 2007). Economies such as Hong Kong, Singapore, Australia, Taiwan, Macau, and South Korea are not only at the top of the scale for the region, but they are also among the top countries worldwide together with Scandinavian, North American, and Western European nations. They help pull the regional average higher than the global average.

Investment in ICT is most intensive and dynamic in services (OECD, 2000). In earlier studies on innovation, the service sector has been characterized as a mere applier of technological innovations developed in the manufacturing sector (Pavitt, 1984). However, more recent empirical studies confirm a more active role of the service sector in the process of technological change (Sirilli \& Evangelista, 1998). Therefore, differences in technological opportunities, appropriability conditions, and the cumulativeness of innovative capabilities may lead to differences in the innovation paths among firms in the service sector.

Authors suggest that the adoption and diffusion of new technologies can be spurred by many different drivers and can have far-reaching consequences or impacts. For this study, an extended SCP paradigm was used as a conceptual framework for the analysis of ICT impacts. Developed by Mason (1939) and Bain (1951), the paradigm states that firm and industry performance is determined by the conduct of buyers and sellers, which is a function of the market structure. 
The term structure goes beyond the market structure characteristics of the original concept. The main features are related to the number and size of firms, the number and preferences of customers, and the level of ease of market entry. Further industry structure characteristics are related to products and production factors: the degree of product differentiation, the degree of vertical integration of production (i.e., the technologies available to firms and the level of competence), and the workforce composition and demand for labor, most importantly with regard to knowledge and skills (Sampler, 1998).

These industry structure components influence a firm's conduct. The most important conduct aspects are production strategies, particularly with regard to inter-firm collaboration as well as outsourcing and organizational change (McAfee, 2006). Finally, a firm's performance is assumed to be the outcome of its conduct. Successful innovations improve firm performance by, for example, reducing production cost, increasing productivity (Maroto \& Rubalcaba, 2008), improving product quality, or enabling it to enter new markets (Jones, et al., 2001; Gera \& Gu, 2004).

In contrast to the standard SCP paradigm, the flow of causality is in fact not one-directional (Nepelski, 2003). As an example of feedback between performance and industry structure, successful and innovative companies are more likely to grow and increase their market share at the expense of less-progressive firms, which transforms the market structure. There may also be feedbacks between conduct and industry structure: for example, depending on the imovation type (i.e., product or process innovation, ICT enabled or not), innovations influence the choice of products manufactured and a firm's cost structure. Innovations may also change the incentives to perform activities in-house versus outsourcing them, and consequently, these may influence the demand for labor and its composition. Moreover, they may further shape the relationships with suppliers and customers, for exaniple with regard to collaboration intensity.

Thus, in the following discussion, it is assumed that firm performance may have a feedback effect on both firm conduct and industry structure, and conduct may have a feedback on structure. This conceptualization allows for an enhanced economic approach that studies the drivers and impacts of ICT and ICT-enabled imnovations at the firm and sector levels.

The SCP model and the bi-directional relationships of its elenents are represented in Figure 2. The model allows us to identify firm and industry dimensions that can be considered as relevant for the adoption and diffusion of ICT, particularly by analyzing the links between ICT adoption and market structure, innovation dynamics, and firm performance. For each of the links to be analyzed, a number of hypotheses are proposed. 


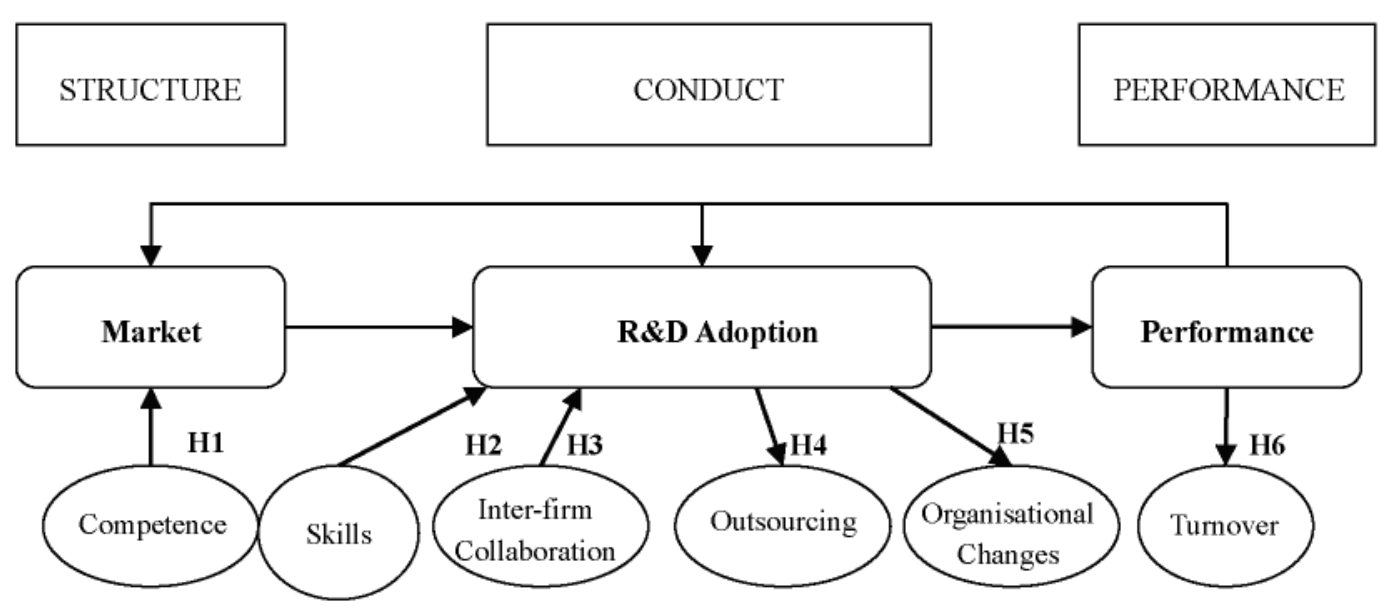

Figure 2: Conceptual Framework for the Analysis of Drivers and Impacts of ICT Adoption

\subsection{ICT and Market Structure}

The increasing competence in the market is an important factor that drives the adoption of new technologies and innovation (Dawe, 1994) as companies search for new opportunities to cut costs by improving process efficiency or developing new products. Firms want to escape competition by innovating, and this can be done by securing a monopoly position, which might stem from a successful innovation protected from imitating by means of a patent, a trademark, or a copyright. Furthermore, just by being the first in the market, a firm may secure an unchallenged position by building up the necessary capacity to enjoy substantial economies of scale or strategic know-how (Eriksson \& Chetty, 2003; Tsai, 2001).

Historically, distance to market and transportation cost limited the number of customers a firm could reach. At the beginning of the Internet era, a common belief was that ICT and e-commerce were to eliminate the limitations of location and enable firms to expand regardless of geographical locations (Cairncross, 1997). In reality, ICT offers existing firms the possibility to expand their market reach, enabling them to cross boundaries (Johnston \& Vitale, 1988), which consequently increases competence.

In the Asia Pacific region, the Asia-Pacific Economic Cooperation (APEC) has been committed to facilitate "free and open trade" among its developed economies by 2010 and among its developing economies by 2020. Trade is looked upon as a strong driver of economic growth, with the idea that increased trade provides more economic opportunities and growth for all. According to the Global Enabling Trade Report 2009 of the World Economic Forum, East Asian economies (Singapore and Hong Kong) occupy the top two 
positions in the Enabling Trade Index ranking, followed by Switzerland, Denmark, and Sweden. Canada, Norway, Finland, Austria, and the Netherlands complete the top 10 list (Table 2).

Table 2: The Enabling Trade Index 2009

\begin{tabular}{l|c|c}
\hline \multicolumn{1}{c|}{ Economies } & Ranks & Scores \\
\hline Singapore & 1 & 5.97 \\
Hong Kong SAR & 2 & 5.57 \\
Switzerland & 3 & 5.44 \\
Denmark & 4 & 5.44 \\
Sweden & 5 & 5.44 \\
Canada & 6 & 5.35 \\
Norway & 7 & 5.33 \\
Finland & 8 & 5.33 \\
Austria & 9 & 5.29 \\
Netherlands & 10 & 5.27 \\
\hline
\end{tabular}

Source: World Economic Forum (2009).

This "new competence" entails flexible response, customization, networking, and new forms of inter-firm organization (clustering) rather than classic price competition dominated by vertically integrated firms (Best, 1990). Based on the foregoing, the following hypothesis can be put forward:

\section{H1: Increasing competence in the market is a driver for the adoption of ICT.}

As pointed out by Cohen and Levinthal (1990), the ability of a firm to recognize the value of new, external information, assimilate it, and apply it to commercial ends is critical to its innovative capabilities. They argue that this absorptive capacity is largely a function of the level of prior related knowledge and skills. First, the absorptive capacity accumulated in a particular area in one period will permit a more efficient accumulation in the next. Second, experienced firms will be able to better predict the nature and commercial potential advancements in an uncertain environment.

Absorptive capacity arises from a long process of investment and accumulation of knowledge through which firms obtain the so-called technological stock (Tsai, 2001). The capacity of firms to internalize technological knowledge becomes a crucial dimension of competition and turns into a critical determinant of their future performance (Lanctot \& Scott, 2000). Thus, in order to develop marketable products or feasible production processes, a firm needs to build up its knowledge stock and expertise, that is, its complementary assets. The most obvious examples of investments in complementary assets include investments in 
software, training, and organizational transformations that accompany ICT investments (Stank, Crum \& Arrango, 1999). In other words, firms that combine high levels of ICT and worker skills have better firm innovation performance. Based on this evidence, the second hypothesis is proposed:

H2: Firms characterized by a higher share of ICT practitioners and employees with a university degree are more likely to conduct ICT-enabled innovations.

\subsection{ICT and Innovation Dynamics}

The growing diffusion of ICT in all areas of business is a major enabler of technological change, innovation, and thus economic development (Clemons \& Row, 1991; Williams, et al., 1997). ICT-driven imnovation activity is central to the subsequent effects of ICT economic impact. This section tries to analyze the degree-specific factors linked with ICT-enabled innovation in the TLS industry and whether companies that conduct ICT-enabled innovation are likely to exhibit superior performance.

ICT has a direct impact on process innovation in an organizational setting by facilitating inter-organizational links (Lee, 2000). ICT-enabled inter-organizational integration and collaboration enhance the innovation capabilities of companies by providing opportunities for shared learning, transfer of technical knowledge, and resource exchange (Gomes \& Park, 1997). The benefits of information integration with the help of ICT are related to the optimization of the value chain, the creation of communication infrastructure facilitating production networks, or the enabling of partners to align the incentives of multiple players by creating joint business units or teams managing the same tasks (Lambert, Cooper \& Pagh, 1998; McAfee, 2006).

Rather than e-commerce, it is the use of electronic networks that leads to a higher probability of firms collaborating in imnovative activities and increases the amount of collaborative relations they have (European Commission, 2004). The use of e-collaboration tools, such as SCM or other applications to share information, is critical to share data with business partners (Baltacioglu, et al., 2007). Hence, the next hypothesis to be tested is as follows:

H3: Firms that use ICT applications to exchange information with business partners are more likely to introduce ICT-enabled innovations.

Following the transaction cost theory, decreasing costs of search, evaluation, and monitoring of suppliers should lead to a shift away from firms and toward markets as a form 
of organizing economic activity (Coase, 1937; Williamson, 1985). Consequently, expectations regarding the potential of ICT as technologies introducing innovative ways of doing business, re-shaping firm boundaries, and changing the constellations of value chains were enormous (Fulk \& DeSanctis, 1995; Milgrom \& Roberts, 1990). The availability of powerful and cheap ICT increases the attractiveness of markets (Lucking-Reiley \& Spulber, 2001) and has spurred firms to focus on their core competencies and reduce their dependency on hierarchy while outsourcing increasing amounts of business activities and services (Erber \& Sayed-Alumed, 2005). Thus, we propose the following hypothesis:

H4: ICT adoption by firms is influenced positively by the degree of outsourcing capacity:

ICT adoption may impact a company's organization, that is, the structure and relationships between departments within a firm. Organizational changes may relate to a rearrangement of functions, workflows, and the importance of departments and employees working in then (Pianta, 2004). The reorganization of production and distribution around ICT has enabled the adoption of new processes, procedures, and organizational structures, which in turn have led to sustainable gains in productivity, quality, and responsiveness (Brynjolfsson \& Hitt, 1996).

ICT transformed the process of replicating business imnovations across organizations (Brynjolfsson, McAfee, et al., 2006). Traditionally, deploying business innovation on a larger scale took time and required considerable involvenent of resources and employees. Today, ICT allows companies to embed business imnovations and then implement them across the organization at a much smaller cost than before without compromising quality (Stoneman \& Kwon, 1996).

The copy-exactly strategy is particularly beneficial if the initial understanding of the process is low, the lifecycle is short, and the process is difficult to improve (Terwiesch \& Wu, 2004). This is true for manufacturing industries with rapidly changing production technologies and intensive technological competition. In such industries, the speed of adoption of new production processes plays a decisive role in remaining at the cutting edge. On the other hand, tools such as e-mail, knowledge management systems, wikis, or instant messaging considerably improve the process of imovation in knowledge-intensive and service-oriented sectors with informal, unstructured, and spontaneous type of work, such as banking (McAfee, 2006). ICT facilitates firms' imovativeness by propagating innovations that are less structured than business processes. This leads to the following hypothesis:

H5: The use of ICT affects organizational changes positively. 


\subsection{ICT and Firm Performance}

The effects of ICT on corporate performance are not clear because not all studies have demonstrated clear payoffs from ICT investments (Kohli \& Devaraj, 2003). In addition, the results vary depending on how performance and ICT payoffs are measured and analyzed. For example, one empirical study found the positive impacts of ICT investments on productivity, but not on profits (Brynjolfsson \& Hitt, 1996). Meanwhile, other studies did not find positive effects of ICT capital on productivity, while ICT labor positively contributed to output and profitability (Prasad \& Harker, 1997).

These somewhat ambiguous results on the impacts of ICT on corporate performance can be explained if one drops the assumption that there is a direct link between ICT investments and corporate performance. The key to understanding the impacts of ICT on performance is to view ICT as an enabler of innovation. Indeed, Clayton and Waldron (2003), in a study on e-commerce adoption and business impact, found that businesses maintaining higher levels of new and improved product sales relative to turnover achieve above sector-average rates of sales growth, that is, they increase market share. The effect is present in both manufacturing and service sectors. Hence, the last hypothesis to be tested is the following:

H6: ICT-enabled innovations affect firms 'performance positively:

\section{Methodology and Results}

\subsection{Data Collection}

The sample studied is comprised of a total of 1,097 firms belonging to the following business activities: land/road and rail transport (NACE Rev. 2, 49.1, 49.2, 49.3, and 49.4) and logistics sectors of warehousing and storage, cargo handling, and other transportation support activities (NACE Rev. 2, 52.10,52.24, and 52.29) to the extent that these sectors interact with transport activities.

The survey was carried out in 2007 in the USA and in seven European countries (France, Germany, Italy, Poland, Spain, Sweden, and the United Kingdom) and was financed by the European Commission through the e-Business Wôtch Programme. The firms were drawn locally based on official statistical records and widely recognized business directories such as Dun \& Bradstreet or Heins and Partner Business Pool. The description of the sample per country is as follows: France (150), Germany (130), Italy (124), Poland (141), Spain (128), 
Sweden (188), the United Kingdom (136) and the USA (100).

The technique employed was a telephone survey. Pilot telephone interviews prior to the regular fieldwork were conducted with about 10 companies in each country in order to test the questionnaire (structure, comprehensibility of questions, and average interview length). In the interviews, not all questions were asked from all companies. We used filter questions to make the interview more efficient; for example, questions on the type of Internet access used were only asked from those companies that indicated they have Internet access. Thus, the question on whether a company has Internet access served as a filter for follow-up questions.

The rate of response was very high $(93.5 \%)$ because in order to achieve the total targeted interviews in the voluntary telephone survey, it was necessary to contact more companies than just the number equal to the target. With regard to the indicators included in the questionnaire, a dichotomous response is applied for respondents.

\subsection{Results Obtained}

To test the hypotheses established in the theoretical model, different regressions were run depending on the critical variables in each case. This method of regression is used to estimate a model using the minimum number of non-superfluous and at the same time significant variables (Guillén, 1992)

Hypothesis 1: The dependent variable, accounting for the intensity of ICT usage, is a set of answers to the questions regarding Internet connection type (less than 144 kbit per second, between $144 \mathrm{kbit}$ and 2 megabit per second, or more than 2 megabit per second), the use of Local Area Network (LAN), Wireless Local Area network (WLAN), World Wide Web (WWW), Intranet, Extranet, Enterprise Resource Planning (ERP), Supply Chain Management (SCM) and Customer Relationship Management (CRM), the use of the Internet to sell and buy goods, and employing IT practitioners (one score for each positive answer). Thus, the variable can take values of between " 0 " and "13." The independent variable indicates whether the conpetence in a firm's market increased in the last 12 months or not and takes a value of " 1 " or " 0 ," respectively. In addition, the regression includes dummy variables controlling the firm size and country of origin. To analyze the relationship between market competence and ICT adoption intensity, ordinary least-squares regression was run (Table 3).

An analysis of the results leads to the conclusion that increasing market competence drives ICT usage. The hypothesized relevance of increasing market competition for the intensity of ICT adoption was confirmed. In other words, a more intense competition forces companies to 
use innovative technologies to cut costs and look for more innovative ways of conducting business. Moreover, firm size is an advantage because it appears to have a considerably strong effect on the adoption of ICT (firms that have more than 249 employees).

Table 3: Effect of Market Competence and the Intensity of ICT Use

\begin{tabular}{c|c|c}
\hline Independent variables & Coefficients & Standard errors \\
\hline Increasing competence & $0.633^{*}$ & 0.257 \\
\hline Less than 249 employees & $-3.637^{* *}$ & 0.471 \\
\hline \multicolumn{2}{l}{ Model diagnostics: N $=932 ;$ R-squared $=0.10$} & \\
\hline
\end{tabular}

Notes: OLS regression; the table does not report country coefficients; *significance at $95 \%$, **ignificance at $99 \%$.

Hypothesis 2: In order to focus on the analysis of ICT-enabled innovations only, a dummy variable was constructed out of companies' answers to the questions on whether the product or service innovations they introduced in the last 12 months were directly related or enabled by information or communication technology. A value of " 1 " is taken if any product or process innovations are directly related to or enabled by ICT, and " 0 " otherwise.

The main explanatory variable is the share of employees with a higher university degree. To additionally account for the effect of internal capacity on innovation, a variable controlling the presence of ICT practitioners was added. This should control the effect of ICT-specific skills on a company's innovative potential. Furthermore, the model also includes variables controlling the firm size and country of origin. Except for the variable on the share of educated employees, all independent variables are dummy variables, taking a value of "1" if a specific characteristic is identified, and " 0 " otherwise. To analyze the relationship between ICT-enabled innovation and the share of ICT practitioners and employees with a university degree, probit regression was run (Table 4).

An analysis of the results leads to the following conclusion: changes in the share of employees with a higher university degree positively affect the likelihood of conducting ICT-enabled innovations. Similarly, employing IT practitioners significantly increases a firm's propensity to use ICT to develop new products and services. This finding provides further evidence that the success of an ICT-driven innovative process depends on the availability and quality of complementary assets. 
Table 4: Effect of Employee Skills on ICT-enabled Innovation

\begin{tabular}{l|c|c}
\hline \multicolumn{1}{c|}{ Independent variables } & Coefficients & Standard errors \\
\hline \% of employees with higher university degree & $0.005^{*}$ & 0.002 \\
\hline ICT practitioners & $0.920^{* *}$ & 0.117 \\
\hline Less than 249 employees & -0.014 & 0.230 \\
\hline
\end{tabular}

Model diagnostics: $\mathrm{N}=845 ; \mathrm{R}$-squared $=0.09$

Notes: Probit estimates; the table does not report country coefficients; *significance at $95 \%$, **significance at $99 \%$.

Hypothesis 3: Again, the analysis focuses only on ICT-enabled innovations. Independent variables control is related to the use of SCM systems and sharing information on inventory levels or production plans electronically with business partners. The regression also includes variables controlling firm size and country of origin. All independent variables are dummy variables, taking a value of " 1 " if a specific characteristic is identified, and " 0 " otherwise. To analyze the relationship between ICT-enabled innovation and the use of electronic data and information exchange between business partners, a probit regression was run (Table 5).

An analysis of the results leads to the following conclusion: the use of applications and practices supporting the electronic exchange of information between companies (e-collaboration tools) positively affects the likelihood of conducting ICT-enabled innovations.

Table 5: Effect of Electronic Collaboration with Business Partners on ICT-enabled Innovation

\begin{tabular}{l|c|c}
\hline \multicolumn{1}{c|}{ Independent variables } & Coefficients & Standard errors \\
\hline Use of SCM & $0.704^{*}$ & 0.139 \\
Share information & $0.599^{* *}$ & 0.122 \\
Less than 249 employees & -0.183 & 0.185 \\
\hline
\end{tabular}

Model diagnostics: $\mathrm{N}=932 ; \mathrm{R}$-squared $=0.09$

Notes: Probit estimates; the table does not report country coefficients; *significance at $95 \%$, **ignificance at $99 \%$.

Hypothesis 4: The dependent variable can take a value of "1" if a company outsourced any of its business activities in the last 12 months or " 0 " if it did not. The explanatory variable controlling a company's ICT endowment level is an index composed of answers to questions regarding Internet connection type (less than $144 \mathrm{kbit}$ per second, between $144 \mathrm{kbit}$ and 2 
megabit per second, or more than 2 megabit per second), the use of LAN, WLAN, WWW, Intranet, Extranet, ERM, SCM, and CRM, the use of the Internet to sell and buy goods, and employing IT practitioners (one score for each positive answer). Thus, the variable can take values between " 0 " and " 13 ." In addition, the regression includes dummy variables controlling firm size and country of origin. To analyze the relationship between outsourcing and ICT adoption, a probit regression was run (Table 6).

Table 6: Effect of Intensity of ICT Use and Outsourcing

\begin{tabular}{l|c|c}
\hline \multicolumn{1}{c|}{ Independent variables } & Coefficients & Standard errors \\
\hline ICT adoption & $0.059^{*}$ & 0.017 \\
Less than 249 employees & 0.050 & 0.237 \\
\hline \multicolumn{2}{l}{ Model diagnostics: $\mathrm{N}=932 ; \mathrm{R}$-squared $=0.051$} \\
\hline
\end{tabular}

Notes: Probit estimates; the table does not report country coefficients; * significance at $99 \%$.

An analysis of the results leads to the following conclusion: ICT intensity increases the propensity to outsource business activities. The more advanced a company is in terms of ICT use, the more likely it is to have outsourced some business activities in the last 12 months. This provides support to the hypothesis that ICT enables companies to redefine their make-or-buy decisions and to outsource business activities that were previously done in-house.

Hypothesis 5: The dependent variable controlling organizational changes is based on companies' answers to the questions of whether they introduced changes in corporate strategy, management techniques, organizational structure, and marketing concepts. For each positive answer, a firm scores one point. Consequently, the dependent variable takes a value of " 0 " if a company did not carry out any of the listed changes and " 4 " if it undertook all of them. In order to account for the various effects of different ICT components on organizations, the explanatory variables include the following:

- Hardware index that comprises the hardware components used by a firm and includes the share of employees with Internet access at their workplace, Internet connection capacity, and the use of LAN, Intranet, and Extranet.

- Software index that comprises the software applications used by a firm. The index includes the following applications: a software application to manage the placing or receipt of orders, ERM, SCM, and CRM, and the use of the Internet to buy and sell goods. 
- ICT human capital variable that controls the presence of ICT practitioners.

In addition, the regression includes dummy variables controlling the percentage of employees with a higher university degree, firm size, and country of origin. To analyze the relationship between ICT-enabled innovation and organizational change, an ordered logit regression was run (Table 7).

Table 7: Effect of ICT Use and Organizational Change

\begin{tabular}{l|c|c}
\hline \multicolumn{1}{c|}{ Independent variables } & Coefficients & Standard errors \\
\hline Infrastructure index & 0.000 & 0.002 \\
\hline Software index & $0.362^{*}$ & 0.060 \\
\hline $\begin{array}{l}\text { ICT practitioners } \\
\text { Percentage of employees with } \\
\text { higher university degree }\end{array}$ & $0.571^{*}$ & 0.195 \\
\hline $\begin{array}{l}\text { Less than 249 employees } \\
\text { Model diagnostics: } \mathrm{N}=651 ; \mathrm{R} \text {-squared }=0.05\end{array}$ & 0.003 \\
\hline
\end{tabular}

Notes: Ordered logit estimates; the table does not report country coefficients; * significance at $99 \%$.

An analysis of the results indicates that ICT hardware has little importance for organizational change. Hardware endowment, measured in terms of network infrastructure usage and Internet access, does not increase the likelihood of introducing organizational changes. On the contrary, software use and ICT practitioners drive organizational changes. The intensity of ICT applications use, particularly the use of ICT-skilled employees, is the major driver of organizational change.

This, together with the previous result, indicates that ICT skills, software, and hardware have different implications for companies' conduct and performance. Whereas hardware is a necessary condition for efficient ICT use, it is not a sufficient condition for business transformation. These are rather human skills combined with innovative software that enable firms to rearrange their operations, functions, and workflows, that is, to find innovative ways of doing business. Hardware infrastructure, in contrast, is already a commodity that does not offer companies any potential to create a competitive advantage.

Hypothesis 6: The analysis focuses only on whether and how ICT-enabled innovations affect firms' performance. The dependent variable is a dummy variable that takes a value of " 1 " if a firm reported a sales increase in the last 12 months or " 0 " otherwise. Explanatory variables control the introduction of any ICT-enabled innovations in the same time period, 
firm size, and country of origin. All independent variables are dummy variables, taking a value of " 1 " if a specific characteristic is identified and " 0 " otherwise. To analyze the relationship between a firm's performance change and ICT-enabled innovation activity, a probit regression was run (Table 8).

An analysis of the results indicates that ICT-enabled output is positively related with performance increase. Firms with a higher incidence of ICT-enabled innovation activity are more likely to report a performance increase (i.e., to have experienced sales growth). Although performance increase was used as a dependant variable, this should not be read as a simple formula for success as there are possible confounding factors such as the growth of a company in general. A similar result might also have been obtained by exchanging the dependent and independent variables, in the sense that successful companies (i.e., firms experiencing performance growth) are more innovative. In any case, the results indicate that the dynamics of business growth and innovativeness are strongly linked, possibly reinforcing each other.

Table 8: Effect of ICT-enabled Innovation Activity on Performance Increase

\begin{tabular}{l|c|c}
\hline Independent variables & Coefficients & Standard errors \\
\hline ICT enabled innovation & $0.300^{*}$ & 0.095 \\
Less than 249 employees & -0.128 & 0.184 \\
\hline \multicolumn{2}{l}{ Model diagnostics: N =932; R-squared $=0.07$} & \\
\hline
\end{tabular}

Notes: Probit estimates; the table does not report country coefficients; * significance at $99 \%$.

\section{Conclusions}

Due to the high turnover and number of jobs in the TLS industry and its interrelation with almost all other economic sectors, any improvements to the competitiveness and effectiveness of transport and logistics companies will have a positive impact on other industries. Over the last few years, firms operating in the TLS sector have made significant progress in their adoption of new technologies, particularly those linked to ICT and e-business. In the USA, some important Asian economies (Korea, Singapore, Japan, Taiwan, and Hong Kong), and in Europe, ICT and e-business activities deployment has thus become increasingly important for the TLS industry, and about $75 \%$ of companies use e-business in one way or another to realize their business activity.

The analysis allows identifying the driving forces of ICT and its impact on selected 
business dimensions. On the driver's side, there are three points that are worth mentioning. First, increasing market competition is one of the driving forces behind ICT usage. In other words, more intense competition allows companies to use imnovative technologies in order to cut costs and look for more innovative ways of conducting business. This in turn enables them to withstand the effect of increasing rivalry. Second, the relationships of companies interacting with each other play an important role in the diffusion of ICT applications supporting inter-firm collaboration. Close relationships facilitate investments in specific technologies. Third, the success of the ICT-driven innovative process depends on the availability and quality of complementary assets such as employee skills and ICT know-how.

On the impacts' side, the following issues draw one's attention. First, companies that are advanced in terms of ICT usage are more likely to have outsourced business activities. This provides support to the hypothesis that ICT enables firms to redefine their make-or-buy decisions. However, a detailed analysis shows that the intensity of ICT applications use, particularly the use of ICT-skilled employees, is the major driver of organizational change. Hardware infrastructure, in contrast, is already a commodity that does not offer companies any potential to create a competitive advantage. Second, ICT usage has a positive impact on company performance, that is, firms that introduced ICT-enabled innovations are more likely to experience sales growth and increased market share.

On the basis of evidence from this study, the following issues have been identified as particularly relevant for policy making. The first is improving ICT skills and managerial understanding and skills for e-business. ICT usage and high levels of employee skills complement each other, leading to skill-biased technological change and an advantage for TLS firms with highly skilled employees in adopting and using ICT. The picture that emerges from the survey is that the use of ICT skills is a decisive key, especially anong SMEs, notably at the managerial level, that is, how e-business is used to support a company's strategy. Training programs must be more focused on managerial understanding and skills for e-business, such as how to effectively integrate e-business processes into existing business models and strategies to change organizational structures.

The second is promoting efforts toward ICT-enabled innovation. The implementation of new ICT and complementary investments can lead to innovations, which are positively associated with sales growth. In other words, imnovative firms are more likely to grow. The enpirical evidence presented in this study corresponds with the theoretical predictions suggesting that ICT and innovation are positively associated with performance at the firm level. Policy makers should envisage the creation of lead programs in fields of excellence such as logistics and transport. 
The last is developing standards for e-business and facilitating the process of interoperability. The importance of standards as a means of reducing transaction cost and increasing competitiveness has been identified as an important barrier to e-business diffusion. Policy measures should allow for temporal and business considerations in a competitive marketplace and may include, as appropriate, active dialogue with the industry on challenges in the formation of value networks and other potential barriers to the implementation of interoperability. Further, it may also include maintenance of an agenda of priority identification, target setting, and monitored progress of interoperability with respect to an evolving priority list of ICT innovation and uptake's functional digital enablers.

\section{References}

Bain, J. S. (1951), "Relation of Profit Rate to Industry Concentration: American Manufacturing 1936-40", Quarterly Joumal of Economics, Vol. 65, pp. 293-324.

Baltacioglu, T., Erhan A., Kaplan, M. D., Oznur, Y. \& Kaplan, Y. C. (2007), "A New Framework for Service Supply Chains" The Service Industries Jounnal, Vol. 27, No. 2, pp. 105-124.

Best, M. H. (1990), New Competition: Institutions of Industrial Restructuring. Boston: The Cambridge Harvard University Press.

Bowersox, D. J. and Calantone, R. J. (1998), "Executive Insights: Global Logistics", Journal of International Marketing, Vol. 6, No.4, pp. 83-93.

Brynjolfsson, E. and Hitt, L. (1996), "Paradox Lost? Firm-level Evidence on the Returns to Information Systems Spending", Management Science, Vol. 42, No. 4, pp. 541-558.

Brynjolfsson, E., McAfee, A., Sorell, M. \& Zhu, F. (2006), Scale Without Mass: Business Process Replication and Industry Dynamics, Harvard Business School Working Paper, No. 07-016.

Cairncross, F. (1997), The Death of Distance: How the Communications Revolution will Change Our Lives, Boston: Harvard Business School Press.

Carayannis, E. and Turner, E. (2006), "Innovation Diffusion and Technology Acceptance: The Case of PKI Technology", Technovation, Vol. 26, No. 7, pp. 847-855.

Clayton, T. and Waldron, K. (2003), "E-commerce Adoption and Business Impact: A Progress Report", Economic Trends, Vol. 591, pp. 33-40.

Clemons, E. K. and Row, M. C. (1991), "Sustaining IT Advantage: The Role of Structural Differences", MIS Quarterly, Vol. 15, No. 3, pp. 275-292.

Coase, R. (1937), "The Nature of the Firm", Economica, New Series, Vol. 4, No. 16, pp. 386-405. 
Cohen, W, and Levinthal, D. (1990), "Innovation and Leaming: The Two Faces of R\&D", Economic Jounnal, Vol. 99, No. 3, pp. 569-596.

Dawe, R. L. (1994), "An Investigation of the Pace and Determination of Information Technology Use in the Manufacturing Materials Logistics System", Jounnal of Business Logistics, Vol. 15, No. 1, pp. $229-260$.

Ellinger, A. E., Daugherty, P. J. \& Gustin, C. M. (1997), "The Relationship between Integrated Logistics and Customer Service", Tronsportation Research Part E, Vol. 33, No. 3, pp. 129-138.

Erber, G. and Sayed-Ahmed, A. (2005), "Off̌shore Outsourcing: A Global Shift in the Present IT Industry", Intereconomics, Vol. 40, No. 2, pp. 100-112.

Eriksson, K. and Chetty, S. (2003), "The Effect of Experience and Absorptive Capacity on Foreign Market Knowledge", International Business Review, Vol. 12, pp. 673-695.

European Commission (2004), E-commerce and Firm Performance: An Assessment Using Multiple Survey Sources and Linked Data, Brussels: EC.

Fulk, J, and DeSanctis, G. (1995), "Electronic Communication and Changing Organisational Forms", Organisation Science, Vol, 6, No. 4, pp. 337-349.

Garten, J. E. (1998), "Why the Global Economy is Here to Stay", Business Week, Vol. 23, pp. 21-29.

Gera, S. and Gu, W. (2004), "The Effect of Organisational Innovation and Information and Communications Technology on Firm Performance", International Productivity Monitor, Vol. 9, pp. 37-51.

Gomes, J. B. and Park, S. H. (1997), "Inter-organisational Links and Innovation: The Case of Hospital Services", Academy of Monagement Joumal, Vol. 40, No. 3, pp. 673-696.

Guillén, M. F. (1992), Análisis de Regresión Múltiple, Madrid: Centro de Investigaciones Sociológicas.

Johnston, H. R. and Vitale, M. (1988), "Creating Competitive Advantage with Inter Information Systems", MIS Quarterly, June, pp. 152-165.

Jones, G. K., Lanctot, J. R., Aldor, T. \& Hildy, J. (2001), "Determinants and Performance Impacts of External Technology Acquisition", Joumal of Business Venturing, Vol. 16, No. 3, pp. 255-83.

Kohli, R. and Devaraj, S. (2003), "Measuring Information Technology Payoff: A Meta-analysis of Structural Variables in Firm-level Empirical Research", Information Systems Research, Vol. 14, No. 2, pp. 127-145.

Lambert, D. M., Cooper, M. C. \& Pagh, J. D. (1998), "Supply Chain Management: Implementation Issues and Research Opportunities", The International Jotmal of Logistics Monagement, Vol. 9 , No. 2, pp. 1-19.

Lanctot, A. and Scott, K. (2000), "Technology Acquisition Strategy in an Internationally Competitive Environment", Joumal of International Management, Vol. 6, No. 3, pp. 187-215. 
Lee, H. L. (2000), "Creating Value through Supply Chain Integration in Supply Chain", Management Review, September/October, pp. 30-36.

Lee, H. L., Padmanabhan, V. \& Whang, S. (1997), "The Bullwhip Effect in Supply Chains", Sloan Management Review, Vol. 38, №. 3, pp. 93-102.

Levary, R. R. (2000), "Better Supply Chains through Information Technology", Indtstrial Management, Vol. 42, No. 3, pp. 24-30.

Lewis, I. and Talayevsky, A. (1997), "Logistics and Information Technology: A Coordination Perspective", Joumal of Business Logistics, Vol. 18, No. 1, pp. 141-157.

Licht, G. and Moch, D. (1999), "Innovation and Information Technology in Services", The Canadian Journal of Economics, Vol. 32, No. 2, pp. 363-383.

Lovelace, K., Shapiro, D. L., \& Weingart, L. R. (2001), "Maximizing Cross-functional New Product Teams' Innovativeness and Constraint Adherence: A Conflict Communications Perspective", Academy of Monagement Journal, Vol. 44, No. 4, pp. 779-793.

Lucking-Reiley, D. and Spulber, D. F. (2001), "Business-to-business Electronic Commerce", Joumal of Economic Perspectives, Vol. 15, No. 1, pp. 55-68.

Maroto, A. and Rubalcaba, L. (2008), "Services Productivity Revisited", The Service Industries Journal, Vol. 28, No. 3, pp. 337-353.

Mason, E. S. (1939), "Price and Production Policies of a Large-scale Enterprise", American Economic Review, Vol. 29, No. 1, pp. 61-74.

McAfee, A. P. (2006), "Enterprise 2.0: The Dawn of Emergent Collatoration", MIT Sloon Review, Vol. 47, No. 3, pp. 21-28.

Merrifield, D. B. (2000), "Changing Nature of Competitive Advantage", Research Technology Management, Vol. 41, No. 1, pp. 41-45.

Milgrom, P. and Roberts, J. (1990), "The Economics of Modern Manufacturing: Technology, Strategy, and Organisation", American Economic Review, Vol. 80, No. 3, pp. 511-528.

Nepelski, D. (2003), The Impact of Innovation on Market Structure - The Case of E-business in the Attomotive Indusiry, Unpublished doctoral dissertation, Humboldt-University, Berlin.

OECD (2000), A New Economy? The Changing Role of Innovation and Information Technology in Growth, Paris: OECD.

Patterson, K. A., Grimm, C. M. \& Corsi, T. M. (2003), "Adopting New Technologies for Supply Chain Management", Transportation Research Part E. Vol. 39, pp. 95-121.

Pavitt, K. (1984), "Sectoral Patterns of Technical Change: Towards a Taxonomy and a Theory", Research Policy, Vol. 13, pp. 343-373. 
Pianta, M. (2004), "Innovation and Employment", in J. Fagerberg, D. Mowery \& R. Nelson (ads.), The Oxford Handbook of Innovation, pp. 568-598, Oxford: Oxford University Press.

Porter, M. E. and Stern, S. (2001), "Innovation: Location Matters", MTT Sloan Management Review, Vol. 42 , No. 4, pp. $28-36$.

Prasad, B. and Harker, P. T. (1997), "Examining the Contribution of Information Technology toward Productivity and Profitability in U.S. Retail Banking", Wharton School Working Paper 97-07, Philadelphia: University of Pennsylvania.

Sampler, J. L. (1998), "Redefining Industry Structure for the Information Age", Strategic Monagement Journal, Vol. 19, pp, 343-355.

Sciadas, G. (2007), "State and Evolution of ICTs: A Tale of Two Asias", in F. Librero \& P. B. Arinto (Eds.), Digital Review of Asia Pacific 2007-2008 (pp. 73-88), Sage/IDRC/Orbicom, New Delhi: Swan Press, available at: http:/wwwidrc.ca/en/ev-116715-201-1-DO_TOPIC.html.

Sirilli, G. and Evangelista, R. (1998), "Technological Innovation in Services and Manufacturing: Results from Italian Surveys", Research Policy, Vol. 27, pp. 881-899.

Stank, T., Crum, M. \& Arrango, M. (1999), "Benefits of Interfirm Coordination in Food Industry Supply Chains", Journal of Business Logistics, Vol. 29, No. 2, pp. 21-41.

Stoneman, P. and Kwon, M. J. (1996), "Technology Adoption and Firm Profitability", Economic Jounal, Vol. 106, No. 437, pp. 952-962.

Tsai, W. (2001), "Knowledge Transfer in Intraorganizational Networks: Effects of Network Position and Absorptive Capacity on Business Unit Innovation and Performance", Academy of Monagement Joumal, Vol. 44, No. 5, pp. 996-1,004.

Terwiesch, C. and Wu, Y. (2004), "The Copy-exactly Ramp-up Strategy: Trading-off Learning with Process Change", IEEE Transactions on Engineering Management, Vol. 51, No. 1, pp. 70-79.

Veliyath, R. and Fitzgerald, E. (2000), "Firm Capabilities, Business Strategies, Customer Preferences, and Hypercompetitive Arenas: The Sustainability of Competitive Advantages with Implications for Firm Competitiveness", Competitiveness Review, Vol. 10, No. 1, pp. 56-82.

Williams, L. R., Nibbs, A., Irby, D. \& Finley, T. (1997), "Logistics Integration: The Effect of Information Technology, Team Composition, and Corporate Competitive Positioning", Journal of Business Logistics, Vol. 18, No. 2, pp. 31-41.

Williamson, O. E. (1985), The Economic Institutions of Capitalism, New York: The Free Press.

World Economic Forum, The Global Enabling Trade Report 2009, http:/www weforum.org/en/ initiatives/gep/GlobalEnablingTradeReport/index.htm. 
